\title{
The Relations Between Authoritarian Leadership and Counterproductive Work Behaviors: The Role of Psychological Resilience
}

\section{Ocel H*}

Department of Psychology, Faculty of Literature, Karabuk University, Turkey

\begin{abstract}
The present study investigates the mediating role of psychological resilience on the relationship between authoritarian leadership and counterproductive work behaviors (sabotage, withdrawal, theft and abuse). The sample consisted of 227 male employee, mostly blue-collar, working in different sectors. Their ages ranged between 23 and 58 . The results showed that psychological resilience partially mediates the relationship between authoritarian leadership and sabotage, withdrawal and theft sub-dimensions of couterproductive work behavior. Mediating role of resilience was not significant for abuse sub-dimension. These findings show that resilience is necessary to overcome the negative consequences of working with authoritarian leader. Hereby, these findings support literature that the psychological resilience ability is a crucial competency in stressful circumtances.
\end{abstract}

Keywords: Authoritarian leadership; Psychological resilience; Counterproductive work behaviors

\section{Introduction}

Counterproductive work behaviors has been specified as a workplace problem [1-4]. Counterproductive work behaviors (CWB), to be specific, voluntary behaviors that violates significant organizational and social norms [5-7] and in turn damages organizations and their stakeholders like employers, supervisors, co-workers, and clients. CWBs may include both overt acts, such as direct aggression and theft, and covert acts, such as purposefully failing to follow instructions or doing work incorrectly etc [8]

Several researches have examined the different factors that could help to understand the process leading to CWB, considering both situational and personal dimensions $[7,9]$. To this extent, the stressoremotion model of CWB $[7,10]$ represents a comprehensive model explaining why workers in stressful conditions may enact CWB at work. In particular, capitalizing on both the frustration-aggression theory developed by Dollard and his colleagues [11] and stress theories $[12,13]$, obscured, giving access to CWB as a plausible behavioral strategy to cope with negative emotions derived from negatively perceived situations. The most commonly studied stressors have been workload and role stressors, such as role conflict, role ambiguity, and role overload. However, researchers have begun to acknowledge the importance of stressors resulting from the social work environment, namely interpersonal conflict [14]. Research has demonstrated leaders themselves can often be a central source of stress among employees [15-17].

\section{Counterproductive Work Behaviors}

Counterproductive work behaviors (CWBs) are behaviors by employees intended to harm their organization or organization members [18]. In the literature, it has been labeled in different ways such as workplace aggression [19], antisocial workplace behavior [20], and workplace deviance [6]. However, despite the specificity of the different definitions provided, all operationalizations share a common emphasis on the actual or potential harmful and detrimental effects of such behaviors on both the organization and its members $[7,20]$. Specific examples of counterproductive work behaviors include stealing from one's employer or co-workers, arriving late for work without permission, intentionally withholding effort, and sabotaging the work of others, to name a few $[6,8,21]$.
Because of the practical implications of counterproductive work behaviors, much research attention has been reserved to identifying the potential antecetends of these behaviors. Some studies, for instance, have investigated the main effects of individual difference variables personality traits $[22,23]$, whereas others have investigated the main effects of work stressors [24-26]. A number studies have also investigated the interactive effects of individual differences and work stressors on counterproductive work behaviors [27,28].

\section{Authoritarian Leadership}

Authoritarian leadership style, also called coercive or dictatorship, involves the manager retaining as much power and decision-making authority as possible. The focus of power is with the leader and all interactions within the group move towards the leader [29,30]. The leader unilaterally exercises all decision-making authority by determining policies, procedures for achieving goals, work task, relationships, control of reward, and punishment [29]. The autocratic leaders believe mainly in the rules and regulations, rewards and punishment as motivation. The subordinates carry out the leader's directives without question(s) and there are no groups inspired decisions.

According to Puni et al. [30] leadership makes possible organizations to be more productive and beneficial, but the extent of success depends on the style of the leader and the resultant environment created for employees to function well [30]. Authoritarian leadership captures behavior that "asserts absolute authority and control over subordinates and demands unquestionable obedience" [31]. Authoritarian leaders are likely to exercise control by initiating structure, issuing rules, promising rewards for compliance, and threatening punishment for disobedience [32]. Similarly Tsui et al. [33] noted that an authoritarian

${ }^{*}$ Corresponding author: Ocel $\mathrm{H}$, Department of Psychology, Faculty of Literature Karabuk University, Turkey, Tel: +90 4440 478; E-mail: hatemocel@hotmail.com

Recieved February 15, 2018; Accepted March 29, 2018; Published April 05, 2018

Citation: Ocel H (2018) The Relations Between Authoritarian Leadership and Counterproductive Work Behaviors: The Role of Psychological Resilience. J Entrepren Organiz Manag 7: 229. doi: 10.4172/2169-026X.1000229

Copyright: (c) 2018 Ocel H. This is an open-access article distributed under the terms of the Creative Commons Attribution License, which permits unrestricted use, distribution, and reproduction in any medium, provided the original author and source are credited. 
leadership style stresses personal dominance over subordinates, centralizes authority on him or herself, and makes unilateral decisions.

Research about causes of counterproductive work behaviors showed that leadership is seen as one of the organizational factors that give rise to deviant behaviors [34]. Stress researchers found that leadership can increase stress if it is too much control-orientated: a leader who continuously gives subordinates instructions such as 'work more quickly', 'work accurately', 'you could do more', 'hurry up, we haven't much time left', generates detectable physiological symptoms of stress among the staff (e.g., increased levels of systolic and diastolic blood pressure) $[35,36]$.

\section{Psychological Resilience}

In a metatheory review of the constructs of resilience and resiliency, Richardson [37] traced different streams of inquiry into these topics. According to the first group of researchers, psychological resilience is viewed as an individual difference in the capacity to bounce back or recover from stress $[38,39]$. The second group of researchers focuse on resiliency as a "process of coping with stressors, adversity, change or opportunity" [37]. Sinclair and Wallston [40] defined resilience as the tendency to "cope with stress in a highly adaptive manner." Britt et al. [41] distinguish between a "capacity for resilience" and a "demonstration of resilience," thereby differentiating personality predispositions and the use of resilience-oriented coping strategies (predictors) from demonstrated adaptation to adverse events. According to Shoss et al. [42] although both streams of research conceptualize resilience somewhat differently, that psychological resilience and resilient coping approaches are intertwined.

Resilient individuals tend to develop strong beliefs, perceive life as meaningful, and be flexible in adapting to change [43]. According to Luthans and Youssef [44] resilience is a state that can be developed, not a fixed trait. Individuals develop resilience over their lifetime as a result of successful cognitive and emotional processing of personal challenges, which result in effective coping strategies that strengthen individuals' responses to challenging circumstances [44].

The assumption is that because resilient individuals seek out the positive in situations, search for creative solutions to difficult challenges, and focus on recovering losses they encounter $[45,46]$, they are less likely to experience the pervasive negative effects of authoritarian leadership. Because resilient individuals seek to adapt to negative situations (i.e., bending instead of breaking), it has been proposed that resilience may be able to buffer the negative impact of authoritarian leadership on a counterproductive work behaviors. Although the literature has documented several beneficial effects of resilience at work [47-49], there is little empirical research on the effects of resilience on counterproductive workplace behaviors [42]. Therefore, the purpose of the present study aimed at examining the mediating role of psychological resilience as an individual characteristic and coping strategy for the impact of authoritarian leadership on counterproductive work behaviors subdimensions sabotage, withdrawal, theft and abuse.

\section{Method}

\section{Sample}

The study sample consisted of 227 individuals whom most of them were blue-collar worker. Respondents work in different sectors such as engineering, technician and job security specialist. Data were collected by convenience sampling. The sample included a wide age range. Respondents were between the ages 23 and $58(\bar{X}=35,93 \mathrm{~S}=6.35)$. More than half of the samples (55.9\%) had a highschool degree. The work experience of the respondents varied between 1 and 25 years $(\bar{X}=9.16$ $S=6.97)$.

\section{Measures}

Authoritarian leadership scale: Authoritarian Leadership Scale was one of the 9-item dimensions of Paternalistic Leadership Scale developed by Cheng et al. [31]. The Cronbach Alpha coefficient of the scale was .89. In addition to this scale, three items selected from Pasa. These three items had supplementary and supportive role for the nineitem scale. Responses were obtained on a fivepoint Likert-type scale ranging between 1 (strongly disagree) and 5 (strongly agree). The 12 item Authoritarian Leadership Scale was adapted to Turkish by Giray [50]. Cronbach Alpha coefficients for the current study was .80.

Psychological resilience scale: The Connor-Davidson Resilience Scale CD-RISC Connor and Davidson [51] is a 25-item scale that measures the ability to cope with adversity. In the present study 10item CD-RISC by Campbell-Sills and Stein [52] was used because this abridged version showed excellent psychometric properties. The scale items reflect the ability to tolerate experiences such as change, personal problems, illness, pressure, failure, and painful feelings. Respondents rate items on a scale from 0 (not true at all) to 4 (true nearly all the time) sample item: "Can deal with whatever comes". Higher scores indicate higher levels of resilience. Higher scores indicate higher degrees of resilience. It is recommended by the authors to use this instrument as a unifactorial scale. The Cronbach Alpha coefficients for 10-item abbreviated version was .80 [53]. Cronbach Alpha coefficients for the current study was .85 .

Counterproductive work behavior checklis: Counterproductive Work Behavior Checklist [8] consists of 33 items. Each item describes a CWB that prevails in workplaces. Respondents are asked to indicate on 5-points Likert type scales the frequency with which they engage in the behaviors described in the items. Response choices range from "never" to "everyday". The scale has five subscales identified as abuse toward others, production deviance, sabotage, theft and withdrawal with Cronbach's alphas ranging from .42 to 81 . The scale was adapted to Turkish by Ocel [54]. The Turkish version of the scale consists of 32 items and four subscales identified as abuse toward others, sabotage, theft and withdrawal. Cronbach alpha coefficients for the current study were .92 for sabotage, .95 , for withdrawal, .93 , for theft and .98 for abuse.

\section{Procedure}

Questionnaires have been distributed to several organizations selected from various sectors. Authoritarian leadership, psychological resilience and counterproductive work behavior measures were provided by the focal study participants. Participants voluntarily responded to a survey during working hours. All participants were informed that participation was voluntary and that no individual or organizational would be identified at any stage of the research.

\section{Results}

All analyses were conducted using SPSS 15.0. Table 1 contains the means, SD, correlations and Cronbach Alfa coefficients for the measured variables. As can be seen in Table 1, all of the scales had acceptable Cronbach Alfa coefficients, given that their coefficients were all greater than 0.60 [55]. Authoritarian leadership had a significant negative correlation with psychological resilience and a significant positive correlation with sabotage, withdrawal, theft and abuse that subdimensions of counterproductive work behavior. 


\begin{tabular}{|c|c|c|c|c|c|c|c|c|c|c|c|c|}
\hline S.No & & M. & SD & 1 & 2 & 3 & 4 & 5 & 6 & 7 & 8 & 9 \\
\hline 1 & Age & 35.93 & 6.35 & & & & & & & & & \\
\hline 2 & Education & 1.96 & 0.75 & $-.46^{\star *}$ & & & & & & & & \\
\hline 3 & Tenure & 9.16 & 6.97 & $0.79^{\star *}$ & $-.27^{* *}$ & & & & & & & \\
\hline 4 & Auth. Lead. & 30.67 & 8.93 & -.04 & -.09 & -.06 & $0.80^{\check{0}}$ & & & & & \\
\hline 5 & Psy. Resil. & 32.66 & 9.39 & 0.07 & -.06 & 0.05 & $-.14^{*}$ & $0.85^{ð}$ & & & & \\
\hline 6 & Sabotage & 3.41 & 1.65 & 0.07 & -.06 & 0.02 & $0.24^{* *}$ & $-.15^{\star}$ & $0.92^{ð}$ & & & \\
\hline 7 & Withdrawal & 6.84 & 3.10 & 0.06 & -.07 & 0.00 & $0.27^{\star *}$ & $-.22^{\star *}$ & $0.85^{\star *}$ & $0.95^{\circ}$ & & \\
\hline 8 & Theft & 6.77 & 3.28 & 0.03 & -.07 & 0.02 & $0.27^{\star \star}$ & $-.23^{* *}$ & $0.81^{\star *}$ & $0.94^{\star *}$ & $0.93^{\circ}$ & \\
\hline 9 & Abuse & 19.06 & 8.83 & 0.04 & -.02 & 0.02 & $0.26^{\star *}$ & $-.19^{* *}$ & $0.80^{* *}$ & $0.91^{* *}$ & $0.91^{* *}$ & $0.98^{\circ}$ \\
\hline
\end{tabular}

${ }^{*} \mathrm{p}<.05,{ }^{* *} \mathrm{p}<.01,{ }^{\circ}$ Cronbach Alfa Coefficient (Subdimensions of Counterproductive Work Behaviors: Sabotage, Withdrawal, Theft, Abuse).

Table 1: Mean (M), Standard Deviation (SD), Internal Consistencies (Cronbach's $\alpha$ ) and Correlataions.

\begin{tabular}{|c|c|c|c|c|c|c|c|c|c|c|c|c|c|}
\hline \multirow[t]{2}{*}{ Variables } & \multicolumn{6}{|c|}{ Sabotage } & \multicolumn{4}{|c|}{ Withdrawal } & \multirow[b]{2}{*}{$\mathrm{t}$} & \multirow[b]{2}{*}{$\mathrm{R}$} & \multirow[b]{2}{*}{$p$} \\
\hline & $\mathrm{R}$ & $\mathrm{R}^{2}$ & $\mathrm{~F}$ & $\beta$ & $t$ & $\mathrm{p}$ & $\mathrm{R}$ & $\mathrm{R}^{2}$ & $\mathrm{~F}$ & $\beta$ & & & \\
\hline Step 1 & 0.11 & 0.01 & 1 & & & & 0.07 & 0 & 0.37 & & & 0.07 & \\
\hline Age & & & & 0.18 & 1.68 & & & & & 0.08 & 0.77 & & \\
\hline Step 2 & 0.28 & 0.08 & 4.6 & & & & 0.3 & 0.09 & 5.54 & & & 0.3 & \\
\hline Age & & & & 0.2 & 1.86 & & & & & 0.1 & 0.95 & & \\
\hline Auth. Lead. & & & & 0.25 & 3.89 & & & & & 0.3 & 4.57 & & \\
\hline Step 3 & 0.31 & 0.09 & 5.51 & & & & 0.36 & 0.13 & 6.4 & & & 0.36 & \\
\hline Age & & & & 0.21 & 2.02 & & & & & 0.12 & 1,19 & & \\
\hline Auth. Lead. & & & & 0.23 & 3.51 & & & & & 0.26 & 4.05 & & \\
\hline Psyc. Resil. & & & & -13 & -1.98 & & & & & -0.19 & -3 & & \\
\hline
\end{tabular}

Table 2: Moderated regression analysis results for sabotage, Withdrawal (Subdimensions of CWB's).

Multiple regression analysis were done to determine of mediator role of psychological resilience on reletionship between authoritarian leadership and sabotage, withdrawal, theft and abuse.

The results of research indicated that psychological resilience would partially mediate the association between authoritarian leadership and sabotage, withdrawal and theft that subdimensions of counterproductive work behaviors. It has been used hierarchical regression for testing the predicted mediation and the Sobel Test to assess the statistical significance of the indirect effects (Table 2).

Hierarchical regression analysis was performed for testing the mediator role of psychological resilience between authoritarian leadership and subdimensions of counterproductive work behaviors which are sabotage, withdrawal, abuse and theft. According to the results, psychological resilience was a partial mediator of the effect of authoritarian leadership on sabotage $(\beta=.88, t=2.55$, R2 change $=.02$, Fchange7,321 $=9.18, \mathrm{p}<.000)$, withdrawal $(\beta=.88, \mathrm{t}=2.55$, $\mathrm{R} 2$ change $=.02$, Fchange7,321 $=9.18, \mathrm{p}<.000)$ and theft $(\beta=.88, \mathrm{t}=2.55, \mathrm{R} 2$ change $=.02$, Fchange7,321=9.18, $\mathrm{p}<.000$ ) (See Tables 2 and 3). According to Baron and Kenny [56], three steps must be fulfilled. In Step 1, the independent variables should predict the mediator. In Step 2, the mediator should predict the outcome variable and in Step 3 the independent variables should predict the outcome variable. Perfect mediation emerges when a previously significant relationship between the independent variables and the dependent variables becomes insignificant with the inclusion of the mediator. When the mediating variable is included in the last equation, a decrase in the coefficients in Step 3 shows an element of mediation (Table 3) [56].

\section{Discussion}

In the present study it has been studied the the mediator role of psychological resilience in the relationship between authoritarian leadership and sabotage, withdrawal, theft and abuse subdimensions of counterproductive work behaviors. According to the results, psychological resilience was a partial mediator of the effect of authoritarian leadership on sabotage, withdrawal and theft but not on abuse. This can be interpreted, as the fact that although people who are supervised with authoritarian leader and have a high level of psychological resilience may accomplish to cope with this stressful situation and do not show counterproductive behaviors that may harm the organization, even if they are working with a autocratic leader. Thus, this findings consistent with $[38,57,58]$ which that resilient individuals are characterized by high positive emotionality and psychological resilience refers to effective coping and adaptation although faced with negative circumstances, hardship, or adversity $[46,59,60]$.

Unexpectedly, psychological resilience was a partial mediator of the effect of authoritarian leadership on abuse subdimension of counterproductive work behaviors (Table 3). This finding could be explained together with Social Exchange Theory. According to the Social Exchange Theory (SET) individuals form relationships with others and maintain it only because they want to increase their benefits $[61,62]$. The theory predicts that individuals who perceive that they are receiving unfavourable treatment are more likely to feel angry, vengeful, and dissatisfied. Consistent with the norms of reciprocity, when individuals are dissatisfied with the organization or their boss, they may reciprocate with negative work behaviours such as withholding effort, arriving late at work, taking longer break times, and leaving early [63].

These consistent findings with literature, demonstrate the robustness of the general idea that psychological resilience is necessary to overcome the consequences of stressful work life resulting from working with an authoritarian leader. Much of the literature on resilience in workplace settings has focused on the main effects of resilience $[49,64,65]$. Whereas this study shows that mediating role of psychological resilience in a stresful situation. Besides, there is no many 
Citation: Ocel H (2018) The Relations Between Authoritarian Leadership and Counterproductive Work Behaviors: The Role of Psychological Resilience. J Entrepren Organiz Manag 7: 229. doi: 10.4172/2169-026X.1000229

Page 4 of 6

\begin{tabular}{|c|c|c|c|c|c|c|c|c|c|c|c|c|}
\hline \multirow{3}{*}{\begin{tabular}{|l} 
Variables \\
Step 1
\end{tabular}} & \multicolumn{7}{|c|}{ Theft } & \multicolumn{4}{|c|}{ Abuse } & \multirow[b]{2}{*}{$p$} \\
\hline & $\mathrm{R}$ & & $\mathrm{F}$ & $\beta$ & $\mathrm{t}$ & $p$ & $\mathrm{R}$ & $\mathrm{R}^{2}$ & $\mathrm{~F}$ & $\beta$ & $\mathrm{t}$ & \\
\hline & 0.05 & 0 & 0.17 & 0.06 & 0.54 & 0 & 0.04 & 0 & 0.17 & 0.06 & 0.53 & 0 \\
\hline \multicolumn{13}{|l|}{ Age } \\
\hline Step 2 & 0.29 & 0.08 & 4.93 & & & & .27 & 0.07 & 4.47 & & & \\
\hline Age & & & & 0.07 & 0.7 & & & & & 0.07 & 0.68 & \\
\hline Auth. Lead. & & & & 0.28 & .4 .37 & & & & & 0.27 & 4.16 & \\
\hline Step 3 & 0.36 & 0.13 & 6.49 & & & & 0.32 & 0.1 & 4.96 & & & \\
\hline Age & & & & 0.1 & 0.98 & & & & & 0.09 & 0.88 & \\
\hline Auth. Lead. & & & & 0.24 & 3.8 & & & & & 0.24 & 3.7 & \\
\hline Psy. Resil. & & & & -0.22 & -3.42 & & & & & -0.16 & -.2 .53 & \\
\hline
\end{tabular}

Table 3: Moderated regression analysis results for theft, Abuse (Subdimensions of CWB's).

studies have examined relationship of the psychological resilience and counterproductive work behaviors [66-69]. Thus, the present findings extend research on counterproductive work behaviors by exploring the role of psychological resilience [70-72]. Together, these results suggest that organizational interventions to boost employee resilience might indeed be able to positively impact employee and organizationally relevant outcomes [73-75]. Hence, it is likely that training interventions that promote the use of resilient coping strategies might help promote positive outcomes and enable employees to more effectively cope with the stress of working with authoritarian leader [76-78].

Although this study is strengthened by the consistent findings it is not without limitations. First limitation is utilization of self-reports $[79,80]$. Undoubtedly, the cross-sectional nature of data makes it more difficult to infer causal relations among variables considered [81-83]. Future longitudinal research should be implemented to confirm and strengthen of the results. Another limitation is that all participants were male and the majority of them were consisting from blu-colour workers. Clearly, we can not generalize to all employees [84,85].

\section{References}

1. Fida R, Paciello M, Tramontano C, Fontaine RG, Barbaranelli C, et al. (2014) An integrative approach to understanding counterproductive work behavior: The roles of stressors, negative emotions, and moral disengagement. $\mathrm{J}$ Bus Ethics 130: 131-144

2. Holtz BC, Harold CM (2013) Interpersonal justice and deviance: The moderating effects of interpersonal justice values and justice orientation. J Manag 39: 339-365.

3. Marcus B, Taylor OA, Hastings SE, Sturm A, Weigelt O (2013) The structure of counter productive work behavior: A review, a structural meta-analysis, and a primary study. J Manag 42: 203-233.

4. Meier LL, Spector PE (2013) Reciprocal effects of work stressors and counterproductive work behavior: A five-wave longitudinal study. J Appl Psychol 98: 529-539

5. Collins JM, Griffin RW (1998) The psychology of counterproductive job performance. Griffin RW, O'Leary-Kelly A, Collins JM (Eds.), Monographs in organizational behavior and industrial relations 23: Parts A \& B. Dysfunctional behavior in organizations: Violent and deviant behavior pp: 219-242 US: Elsevier Science/JAI Press.

6. Robinson SL, Bennett RJ (1995) A typology of deviant workplace behaviors: A multidimensional scaling study. Acad Manag J 38: 555-572.

7. Spector PE, Dollard S (2005) A model of counterproductive work behavior Fox S, Spector PE Counter productive workplace behavior: Investigations of actors and targets pp: 151-174. Washington, DC, US: American Psychological Association.

8. Spector PE, Fox S, Penney LM, Bruursema K, Goh A, et al. (2006) The dimensionality of counterproductivity: Are all counterproductive behaviors created equal? J Vocat Behav 68: 446-460.

9. Bowling NA, Eschleman KJ (2010) Employee personality as a moderator of the relationships between work stressors and counterproductive work behavior. J Occup Health Psychol 15: 91-103.
10. Spector PE (1998) A control theory of the job stress process. Cooper CL Theories of organizational stress 153-169 Oxford: Oxford University Press

11. Dollard J, Doob CW, Miller NE, Mowrer OH, Sears RR (1939) Frustration and aggression. New Haven, CT: Yale University Press.

12. Jex SM, Beehr TA (1991) Emerging theoretical and methodological issues in the study of work-related stress. Research in personnel and human resources management, pp: 311-365

13. Lazarus RS (1999) Stress and emotion. A new synthesis. New York: Springer

14. Keenan A, Newton TJ (1985) Stressful events, stressors and psychological strains in young professional engineers. J Organ Behav 6: 151-156.

15. Basch J, Fisher CD (2000) Affective events-emotions matrix: A classification of work events and associated emotions. Ashkanasy NM, Hartel CE, Zerbe WJ editors. Emotions in the workplace: Research, theory, and practice, (pp: 36-48) Westport, CT, US: Quorum Books/Greenwood Publishing Group.

16. Offermann LO, Hellmann PS (1996) Leadership behavior and subordinate stress: A 360" view. J Occup Health Psychol 1: 382-390.

17. Sosik JJ, Godshalk VM (2000) Leadership styles, mentoring functions received and job-related stress: A conceptual model and preliminary study. J Organ Behav 21: 365-390.

18. Bennett RJ, Robinson SL (2000) Development of a measure of workplace deviance. J Appl Psychol 85: 349-360.

19. Neuman JH, Baron RA (1998) Workplace violence and workplace aggression: Evidence concerning specific forms, potential causes, and preferred targets. J Manag 24: 391-419.

20. Giacalone RA, Greenberg J (1997) Antisocial behavior in organizations Thousand Oaks CA,US: Sage Publications.

21. Gruys ML, Sackett PR (2003) The dimensionality of counterproductive work behavior. Int J Sel Assess 11: 30-42.

22. Berry CM, Ones DN, Sackett PR (2007) Interpersonal deviance, organizational deviance, and their common correlates: a review and meta-analysis. J Appl Psychol 92: 410-424.

23. Salgado JF (2002) The big five personality dimensions and counterproductive behaviors. Int J Sel Assess 10: 117-125

24. Bruk-Lee V, Spector PE (2006) The social stressors-counterproductive work behaviors link: Are conflicts with supervisors and coworkers the same? J Occup Health Psychol 11: 145-156.

25. Chen PY, Spector PE (1992) Relationships of work stressors with aggression, withdrawal, theft and substance use: An exploratory study. J Occup Organ Psycho 65: 177-184.

26. Diefendorff JM, Mehta K (2007) The relations of motivational traits with workplace deviance. J Appl Psychol 92: 967-977.

27. Fox S, Spector PE, Miles D (2001) Counterproductive work behavior (CWB) in response to job stressors and organizational justice: Some mediator and moderator tests for autonomy and emotions. J Vocat Behav 59: 291-309.

28. Penney LM, Spector PE (2002) Narcissism and counterproductive work behavior: Do bigger egos mean bigger problems? Int J Sel Assess 10: 126-134

29. Mullins LJ (1999) Management and Organizational Behaviour. London: Financial Times. 
Citation: Ocel H (2018) The Relations Between Authoritarian Leadership and Counterproductive Work Behaviors: The Role of Psychological Resilience. J Entrepren Organiz Manag 7: 229. doi: 10.4172/2169-026X.1000229

Page 5 of 6

30. Puni A, Ofei B, Okoe A (2014) The effect of leadership styles on firm performance in Ghana. Int J Mark Stud 6: 177-185.

31. Cheng BS, Chou LF, Wu TY, Huang MP, Farh JL (2004) Paternalistic leadership and subordinate responses: Establishing a leadership model in Chinese organizations. Asian J Soc Psychol 7: 89-117.

32. Aryee S, Chen ZX, Sun LY, Debrah YA (2007) Antecedents and outcomes of abusive supervision: Test of a trickle-down model. J Appl Psychol 92: 191-201.

33. Tsui AS, Wang H, Xin K, Zhang LH, Fu PP (2004) "Let a thousand flowers bloom": Variation of leadership styles among Chinese CEOs. Organ Dyn 33: 5-20.

34. Mbah SE, Ikemefuna CO (2011) Job satisfaction and employee turnover intentions in Total Nigeria plc in Lagos State. Int J Human Soc Sci 2: 275-287.

35. Misumi J (1985) The behavioral science of leadership: An interdisciplinary Japanese research Program MF Peterson, Ann Arbor MI US: The University of Michigan Press.

36. McCormick CP, Powell B (1988) Management for the 1990s. Newsweek, pp: 47-48.

37. Richardson GE (2002) The metatheory of resilience and resiliency. J Clin Psychol 58: 307-321

38. Block J, Kremen AM (1996) IQ and ego-resiliency: Conceptual and empirical connections and separateness. J Pers Soc Psychol 70: 349-361.

39. Smith BW, Dalen J, Wiggins K, Tooley E, Christopher P, et al. (2008) The brief resilience scale: Assessing the ability to bounce back. Int J Behav Med 15 194-200.

40. Sinclair VG, Wallston KA (2004) The development and psychometric evaluation of the brief resilient coping scale. Assessment 11: 94-101.

41. Britt TW, Shen W, Sinclair RR, Grossman MiR, Klieger DM (2016) How much do we really know about employee resilience? Ind Organ Psychol 9: 378-404.

42. Shoss MK, Jiang L, Probst TM (2016) Bending without breaking: A two-study examination of employee resilience in the face of job insecurity. J Occup Health Psychol 23: 112-126

43. Rosenstein AH, Naylor B (2012) Incidence and impact of physician and nurse disruptive behaviors in the emergency department. J Emerg Med 43: 139-148.

44. Luthans F, Youssef CM (2004) Human, social, and now positive psychological capital management: Investing in people for competitive advantage. Organ Dyn 33: $143-160$

45. Bonanno GA (2004) Loss, trauma, and human resilience: Have we underestimated the human capacity to thrive after extremely aversive events? Am Psychol 59: 20-28.

46. Tugade MM, Fredrickson BL (2004) Resilient individuals use positive emotions to bounce back from negative emotional experiences. J Pers Soc Psychol 86 320-333.

47. Luthans F, Avolio BJ, Walumbwa FO, Li W (2005) The psychological capital of Chinese workers: Exploring the relationship with performance. Manag Organ Rev 1: 249-271.

48. Shin J, Taylor MS, Seo MG (2012) Resources for change: The relationships of organizational inducements and psychological resilience to employees' attitudes and behaviors toward organizational change. Acad Manag J 55: 727-748.

49. Youssef CM, Luthans F (2007) Positive organizational behavior in the workplace: The impact of hope, optimism, and resilience. J Manag 33: 774-800.

50. Giray MD (2010) is yerinde destek algılarının liderlik stilleri ve örgütsel sonuç değişkenleri ile ilişkisi. Yayınlanmamış doktora tezi, Hacettepe Üniversitesi, Ankara.

51. Connor KM, Davidson JR (2003) Development of a new resilience scale: the Connor Davidson Resilience Scale (CD-RISC) Depression and Anxiety 18: 76-82.

52. Campbell-Sills L, Stein MB (2007) Psychometric analysis and refinement of the Connor-Davidson Resilience Scale (CD-RISC): Validation of a 10-item measure of resilience. J Trauma Stress 20: 1019-1028.

53. Ikizer G (2014) Factors related to psychological resilience among survivors of the earthquakes in Van, Turkey. Middle East Techinal University.

54. Ocel H (2009) Calisanlarin orgutsel vatandaslik ve uretim karsiti is davranislarinin nedenlerine iliskin bir model onerisi. Yayinlanmamis doktora tezi Ankara Universitesi.
55. Hair J, Anderson R, Tatham R, Black W (1998) Multivariate Data Analysis Englewood Cliffs, NJ: Prentice-Hall.

56. Baron RM, Kenny DA (1986) The moderator-mediator variable distinction in social psychological research: Conceptual, strategic, and statistical considerations. J Pers Soc Psychol 51: 1173-1182.

57. Klohnen EC (1996) Conceptual analysis and measurement of the construct of ego-resiliency. J Pers Soc Psychol 70: 1067-1079.

58. Wolin SJ, Wolin S (1993) Bound and determined: Growing up resilient in a troubled family. New York: Villard.

59. Lazarus RS (1993) Coping theory and research: Past, present, and future Psychosom Med 55: 234-237.

60. Masten AS (2001) Ordinary magic: Resilience processes in development. Am Psychol 56: 227-238.

61. Blau PM (1964) Exchange and power in social life. New York: John Wiley and sons.

62. Emerson RM (1972) Exchange theory, Part II: Exchange relations and networks. Berger J, Zelditch Jr M, Anderson B, Sociological theories in progress pp: 5887 Boston: Houghton Mifflin.

63. Emerson RM (1976) Social exchange theory. Annu Rev Sociol 2: 335-362.

64. Cooke FL, Cooper B, Bartram T, Wang J, Mei H (2016) Mapping the relationships between high-performance work systems, employees resilience and engagement: A study of the banking industry in China. Int J Hum Resour Man pp: 1-22.

65. Laschinger HK, Wong C, Regan S, Young-Ritchie C, Bushell P (2013) Workplace incivility and new graduate nurses' mental health. J Nurs Adm 43 415-421.

66. An M, Boyajian ME, O'Brien KE (2016) Perceived victimization as the mechanism underlying the relationship between work stressors and counterproductive work behaviors. Human Performance 29: 347-361.

67. Bass BM (1990) From transectional to transformational leadership. Learning to share the vision. Organ Dyn 18: 19-31.

68. Berkowitz L (2003) Affect, aggression, and antisocial behavior. Davidson RJ, Scherer KR, Goldsmith HH, Series in affective science. Handbook of affective sciences pp: 804-823. New York, NY, US: Oxford University Press.

69. Chen S, Westman M, Hobfoll SE (2015) The commerce and crossover of resources: Resource conservation in the service of resilience, Stress and Health. Stress Health 31: 95-105.

70. Cullen MJ, Sackett PR (2003) Personality and counterproductive work behavior. Barrick M, Ryan AM editor. Personality and work içinde (150-182) San Francisco: Jossey-Bass.

71. Detert JR, Trevino LK, Burris ER, Andiappan M (2007) Managerial Modes of Influence and Counterproductivity in Organizations: A Longitudinal BusinessUnit-Level Investigation. J Appl Psychol 92: 993-1005.

72. Dooley LN, Slavich GM, Moreno PI, Bower JE ( (2017) Strength through adversity: Moderate lifetime stress exposure is associated with psychological resilience in breast cancer survivors. Health Stress 33: 549-557.

73. Greenberg J, Scott KS (1996) Why do workers bite the hands that feed them? Employee theft as a social exchange process. Staw BM , Cummings LL Research in organizational behavior: An annual series of analytical essays and critical reviews 18: 111-156). US: Elsevier Science/JAI Press.

74. Karairmak O (2010) Establishing the psychometric qualities of the ConnorDavidson Resilience Scale (CD-RISC) using exploratory and confirmatory factor analysis in a trauma survivor sample. Psychiatry Res 179: 350-356.

75. Kiazad K, Restubog SLD, Zagenczyk TJ, Kiewitz C, Tang RL (2010) In pursuit of power: The role of authoritarian leadership in the relationship between supervisors' Machiavellianism and subordinates' perceptions of abusive supervisory behavior. J Res Pers 44: 512-519.

76. Martinko MJ, Gudlach MJ, Douglas SC (2002) Toward an integrative theory of counter productive workplace behavior: A causal reasoning perspective. Int $\mathrm{J}$ Sel Assess 10: 36-50.

77. Martinko M J, Zellars KL (1998) Toward a theory of workplace violence and aggression: A cognitive appraisal perspective. In: Griffin RW, O'Leary-Kelly A, Collins JM editors. Monographs in organizational behavior and industria 
Citation: Ocel H (2018) The Relations Between Authoritarian Leadership and Counterproductive Work Behaviors: The Role of Psychological Resilience. J Entrepren Organiz Manag 7: 229. doi: 10.4172/2169-026X.1000229

Page 6 of 6

relations 23: Parts A \& B. Dysfunctional behavior in organizations: Violent and deviant behavior (pp: 1-42) US: Elsevier Science/JAI Press.

78. O'Brien KE, Allen TD (2008) The relative importance of correlates of organizational citizenship behavior and counter productive work behavior using multiple sources of data. Human Performance 21: 62-88.

79. Ocel H, Aydin O (2010) The Impact on Fair Business and Behavior Against Sexuality Production . Turk Psikoloji Dergisi 25: 73-83.

80. Penney LM, Spector PE (2005) Job stress, incivility, and counterproductive workplace behavior (CWB): The moderating role of negative affectivity. J Organ Behav 26: 777-796.
81. Puni A, Agyemang CB, Asamoah ES (2016) Leadership styles, employee turnover intentions and counterproductive work behaviours IJIRD 5: 1-7.

82. Reivich KJ, Seligman MEP, McBride S (2011) Master resilience training in the U.S. Army. Am Psychol 66: 25-34.

83. Rutter M (1987) Psychosocial resilience and protective mechanisms. Am J Orthopsychiatry 57: 316-331.

84. Tannenbaum R, Schmidt WH (1957) How to choose a leadership pattern. Harv Bus Rev 36: 95-101.

85. Woodgate RL (1999) Conceptual understanding of resilience in the adolescent with cancer: Part I. J Pediatr Oncol Nurs 16: 35-43. 